\title{
14 Conclusion and perspectives
}

\author{
Haldor Byrkjeflot, Mads Mordhorst and \\ Klaus Petersen
}

The Nordic model is an ambiguous concept. It changes, it flows, and it emerges in new fields with new carriers and purposes. This insight is almost as old as research on the Nordic model, but in this volume, we have made the ambiguity our point of departure and integrated it as part of our approach. We sketch out this approach in Chapters 1 (Introduction) and 2. Here we stress how the idea of a Nordic model is not only a matter of balancing similarities and differences between the Nordic nation states, as is most often the case in previous research, but also a matter of studying the influence of external factors, and to link the domestic, Nordic, and international levels. While the 'Nordic model' thus for the most part has been used in the singular, our empirical studies in this volume have demonstrated it is a rather plastic and pluralistic concept.

In order to better understand the processes behind the transformation and developments of the Nordic models, we have throughout the book focused on the empirical circulation, translation, and diffusion of the models and associated concepts like the Swedish- and Scandinavian models. This transnational perspective allows us to grasp how the model has been conceptualized, traveled, and changed over time and place and how it has entered into various spheres through different networks and actors with different semantics. The chapters in this book analyze different dimensions and layers of the model, showing that the routes and ways of how the model travel and circulate are non-linear, sometimes even paradoxical, and random. However, from a bird's-eye view, the empirical richness of the individual chapters allows us to point out some patterns and trajectories in the circulation-routes of the 'Nordic model.'

Our transnational perspective makes it visible that the Nordic model has, over time, become a globalized concept as well as a globalizing concept. It has become an integrated part of global discourses and surfaces a variety of places and with different directions of circulation. This clearly questioned the image of a one-way diffusion of ideas originating exclusively in the Nordic region. The chapters in this book demonstrate that the Nordic model(s) do not always emerge in the Nordic region or have the Nordic region as a part of the intended target audience.

DOI: $10.4324 / 9781003156925-16$ 
Several chapters analyze how Nordic models were strategically constructed and used by networks and stakeholders outside the Nordic region. In France, the Swedish model was mobilized in the aftermath of the student rebellion in 1966, in a way the Swedish social democrats first rejected, as an expression of the model (Chapter 5). In a similar way, the idea of 'Scandinavian Design' (Chapter 13) emerged in postwar North America. A more contemporary example is the use of references to the Nordic model in British healthcare policy over the last decades (Chapter 11), as part of a New Public Management agenda promoting privatization and marketization, in contrast to the historical Nordic traditions and experiences.

However, the routes of travel include more than a spatial and geographical perspective. The models also move between different spheres and diffuse into new fields and sectors. Mjøset (Chapter 3) discusses how the idea of a Nordic model traveled between the political and academic spheres and changed in this process. Other chapters discuss how the model has diffused to the cultural sphere (Chapter 13) and how the Nordic model is strategically mobilized as template and brand in the creation of the New Nordic Cuisine (Chapter 12).

Within academia, we find a diversity of ways to research the Nordic model, from ambitions for synthetic concepts to more social constructivist approaches. In politics, the search for the model is more of the normative kind - models may be ranked and compared, used as a benchmark or as justification for reforms or political programs. This includes also negative use, where reference to a model point out policies that are to be avoided (see, e.g., Chapter 4). As the models travel between the different spheres, they are translated or innovated by new actors and adapted to new purposes. When the ombudsman institution was imported into North America in the 1960s, it happened in a way rather ignorant of Nordic experiences (see Chapter 8). At first, the Nordic origin was regarded as a positive feature. However, as the first attempts of adoption failed, US promoters of the ombudsman changed to a strategy of domesticating, i.e., getting rid of all references to its origin and instead emphasized the cultural fit with American values. We find similar ways of domestication and translation taking place in the case of the Norwegian model of board quotas (Chapter 10). When this model was lifted to the EU-level, its source of origin was largely hidden (Inderhaug, 2018).

In these domestication and translation processes, we see a very diverse set of actors involved, such as international organizations, media, ranking and rating agencies, and not the least policy entrepreneurs, activist networks, and epistemic communities. Arguably, networks tend to become more complex over time with the growing importance of social media, global policy exchange, and new arenas for exchange between experts and policymakers. The expanded circulation of policy ideas imported from the Nordics reported in Chapter 9 on prostitution regulation or in Chapter 7 on development aid reflects the existence of such ecosystems of policy professionals and activists. 
In some cases, we find rivalry between the Nordic countries about being acknowledged as the source for the ideas that are exported as 'Nordic.' In most cases, Sweden appears as the dominant point of reference (see Chapters 4-6). In the case of the board quota model (discussed in Chapter 10), it travels as a Norwegian model. The prostitution regulation model (discussed in Chapter 9), however, has been imported into five countries as a Nordic model although it is also only Norway, Sweden, and Iceland among the Nordics that have put into effect that model. In this way, we find examples where Nordic and national branding ambitions clash as well as examples where they go hand in hand and mutually reinforce each other (Chapter 13). However, from a national branding perspective, branding agents and public diplomats wanting to control the spread of the models are confronted with an impossible task since it is rather international activist and policy networks who may take control and choose the labels and models that serve their cause best.

In the field of culture, the Nordic model is framed as an aesthetic category, integrating elements such as landscape, light style, and historical narratives in definition, as often seen in the successful use of it in art, crime fiction, TV-series, and lifestyle products. These aesthetics elements are in the commercial sector often translated into brand images and utilized, as a means for profit, such as when it was used to create and renew Scandinavian Design (Chapter 13) or when high-profiled Nordic chefs wrote the manifest for the New Nordic Cuisine (Chapter 12). The use of the Nordic model as brand is, however, not limited to the commercial sector. Several contributions in the book exemplify how the Nordic model has been used as a brand for exporting political ideas and models. Chapter 4 analyses how diplomats use the Swedish and Nordic welfare models as a brand for promoting Swedish interests. Chapter 9 points out how Swedish and Norwegian political legislation was transformed into an international brand by feminist NGO organizations through the framing of it as the Nordic Model of prostitution regulation. Again, we see how the models are circulated and translated through actor networks representing different interests and purposes.

Held together, the historical case studies in the book indicate changes in the use of the Nordic model over time. Models such as the 'Nordic model of Prostitution Regulation' and the 'New Nordic Cuisine' are recent phenomena, while other models have lost in traction. Some models are sticky and have long lives, whereas other models are short-lived fitting only a specific moment in time. From the interwar period up to the 1980s, 'welfare,' 'Sweden,' 'progressive,' and 'social democratic' were often seen as the core of the model (see especially Chapters 2-6). This seem to have changed somewhat over the last few decades where some of the good old virtues have lost traction, and as pointed out in Chapters 4 and 11, the Nordic model(s) became more contested. This paved the way for new understandings of the Nordic model (as discussed above), at the same time as the classical images continued to carry some weight (see Chapter 2 on the duality of the Nordic model). 
When we started this book project five years ago, it was under the impression that the Nordic models were gaining in attraction. The Nordics were dominating international rankings as the happiest, least unequal, most gender friendly countries (Stende, 2017). As argued by Kangas (2000), looking behind the Rawlsian 'veil of ignorance,' allows us to choose the country in which we want to live but without knowing the particular socioeconomic circumstances in which we will be living, the Nordic model would, indeed, be a rational choice. These impressions were backed by international attention. In 2013, The Economist declared the Nordic model as 'the next supermodel,' and prior to this, the 'Nordic way' was on the formal agenda of the 2011 Davos meeting (World Economic Forum, 2011). At a 2016 state dinner, President Obama proclaimed that the world would be in a better place if it followed the 'Nordic way' (The White House, 2016). Even in the cultural and lifestyle spheres, the Nordic model and 'Nordicness' were in vogue and high demand in areas such as Nordic living and lifestyle (Hygge), Nordic Noir, and New Nordic Cuisine.

Even though this was just a few years ago, the world has changed in rather remarkable ways. In 2016, the United Kingdom voted to leave the European Union and shortly after Donald Trump was elected president in the United States. Populism is flourishing also in Europe, challenging the traditional way of doing politics. New movements such as Black Live Matters and MeToo have emerged on the scene and challenged established social and cultural orders. In 2015-2016, Europe experienced a refugee crisis, and in 2020-2021, the world is in the middle of the COVID-19 global pandemic. These are events that will shatter and shape the world around us in the coming decades - and they will also affect the Nordic model(s) and the international circulation of the model(s).

We do not claim to be able to predict the future in any detail. Far from that. However, we believe that the historical approach and the empirical case studies offered in this book can also serve as a framework for understanding more recent developments and changes. What is needed in a period with dramatic social and political change is historical sensitivity and an open analytical framework. Understanding the changing normative chartings of the 'Nordic model' - its dualities - for example, allows us to better understand the changing use of 'the Nordic model' in recent US political debates.

With the election of Donald Trump, the use of the Nordic model in US political rhetoric changed. Obama's positive narrative of countries 'who punch above their weight' and 'the Nordic way' (White House, 2016) stands in sharp contrast to Trump's rhetoric of the Nordic Countries as dystopian pictures of violent and dysfunctional socialist states. At a rally in 2017, Trump said 'look at what happened last night in Sweden,' falsely implying that there had been a terror attack due to Swedish asylum politics (Chang, 2019). Likewise, The Trump White House published a report, 'The Opportunity Costs of Socialism' in 2018 (Council of Economic Advisors, 2018), framing the Nordic countries as cases demonstrating that 
socialism leads to reduced living standards. In a similar vein, Fox News host Trish Regan characterized Denmark as a failed socialist state in line with Venezuela. However, this was not the only image of the Nordic model circulating in US political discourse. The progressive Democrat Bernie Sanders presented the Nordic model as a utopian model for the future of the United States during the primaries, where he used it as part of his program for 'democratic socialism.' As socialist ideas, in various forms, seem to gain some popularity especially among younger cohorts in the United States and elsewhere, protagonists and antagonists will revisit historical experiences such as the Nordic experience, and this might well trigger also renewed interest in the historical heritage within the Nordic region. As we demonstrate in the book, these dystopian/utopian stereotypes have been a recurrent figure in American political discourse since the 1930s (see especially Chapters 2 and 4). Renewed debate serves as a rich reservoir also for contemporary observers and public actors and, like history, often repeats itself.

Other kinds of circulation and diffusion of the Nordic model have emerged because of Brexit. The Scottish Government, being against Brexit, saw the Nordic region as a way for Scotland to dissociate itself from England in a post-Brexit time. In a 2017 report titled 'All points north,' the Scottish government launched the idea of a 'New North' including Scotland in the Nordic region due to the historical and political bonds between Scotland and the Nordics. Some have even argued that Scotland should leave the United Kingdom and seek to become members of the Nordic Council (Tømmerbakke, 2020).

In the Nordic region, the 2015 refugee crises and the 2020-2021 COVID-19 pandemic brought the regional cohesion into question. Both events have led to a reactivation of border control and even closed borders. Historically, open borders and the Passport Union between the Nordic countries have symbolized the unity of the region. However, as the caravans of refugees from Syria came to the national borders, the Nordic nations took very different precautions (Brochmann, 2017). Denmark, bordering to continental Europe, reacted with anti-immigrant policies and closing of borders to prevent refugees from entering the country. Internationally, this led to accusations of inhumane behavior, and Denmark faced the largest negative media storm since the 2005 Cartoon crisis (Mordhorst, 2016). Sweden took the almost opposite route, as its government perceived the situation as a humanitarian crisis and consequently saw it as Sweden's national duty to help the asylum-seekers.

Similarly, the COVID-19 pandemic challenged the image of Nordic unity. Sharing the same basic goal of securing public health and sheltering the population from downturns in the economy, the Nordic countries show divergent responses to the pandemic, both in terms of strictness and the extent to which decisions have been delegated to agencies and the regional and local level. Here, Sweden is the odd country out, scoring significantly lower on 
strictness and higher on level of delegation. Sweden has avoided, to a large degree, the draconic lockdowns of schools, workplaces, and shops, which we find in the other Nordic countries. Also, the effects of the crisis differ in significant ways with Sweden's much higher death rate, which have led the other Nordic countries to temporarily closing borders to Sweden in order to avoid 'import infection.' This, along with disagreements among experts, has provoked tensions within the Nordic region and confusion in international media over what the 'Nordic model' signifies. The dominant image is Sweden as a highly problematic model, while the other Nordic countries are doing rather well.

As we demonstrate in the book, such internal Nordic divergence is nothing fundamentally new. However, it is hard not to see that the highly diverse reactions to such external threats might challenge the basic idea of a Nordic model. It has been argued that part of problems for Nordic cooperation and coordination lately relates to an overemphasis on the promotion of Norden as a brand rather than the earlier emphasis on dialogue and everyday cooperation (Strang, 2016). We find growing tensions around the use of the Nordic model as regional identity versus using it as brand. Illustrative in this respect is the heated debate around a SAS (Scandinavian Airline System)'s TV-commercial 'What is truly Scandinavian?' in February 2020, just before the Covid-19 crisis took off (SAS, 2020). The message in the controversial commercial is that things and traditions we claim to be of Scandinavian origin are rather international phenomena that Scandinavians brought back from their journeys across the world and then improved and re-exported as 'Scandinavian.' The commercial initiated a 'shitstorm' within the Nordic region where many found it disrespectful to Nordic heritage and history. 'What is truly Scandinavian?' thus initiated two processes of circulation: One as brand-image for SAS, and another as a part of an internal Scandinavian discussion of values and identity.

The changes we have seen in the world order in the last few years have thus far not led to a discontinuation or decline in the circulation and diffusion of 'Nordic models.' The models have been incorporated in new discourses, in processes where some of the already known layers of meanings have been reactivated, and new elements added. The ambiguity of the Nordic model, which makes it impossible to define once and for all, at the same time makes it a concept highly suitable for adaptions and survival. The pandemic, climate crisis, the quest for a more green economy, digitalization and artificial intelligence, increasing inequality (global and national), and the challenges of transnational governance are just a few of the major societal challenges that will change the world and the Nordic model. Clearly, it will not be the same as today, as the model of today, differs in significant ways from 30,50 , or 70 years earlier. Consequently, rather than asking what is the future of the Nordic model, it might be better to ask what is the future Nordic model? 


\section{References}

Brochmann, G. (2017), 'Immigration Policies of the Scandinavian Countries', in P. Nedergaard and A. Wivel (eds.), The Routledge Handbook of Scandinavian Politics (London: Routledge), 229-239.

Chan, S. (2019), “Last Night in Sweden”? Trump's Remark Baffles a Nation', The New York Times, available at https://www.nytimes.com/2017/02/19/world/europe/ last-night-in-sweden-trumps-remark-baffles-a-nation.html [accessed March 9, 2021]

Council of Economic Advisors (2018), The Opportunity Costs of Socialism, available at https://permanent.fdlp.gov/gpo111203/The-Opportunity-Costs-of-Socialism. pdf [accessed March 18, 2021]

Inderhaug, E. (2018), 'En norsk likestillingsreform I EU', in C. Holst, H. Skjeie and M. Teigen (eds.), Europeisering av nordisk likestillingspolitikk (Oslo: Gyldendal Akademisk), 194-217.

Kangas, O. (2000), 'Distributive Justice and Social Policy: Some Reflections on Rawls and Income Distribution', Social Policy and Administration, 34(5), 2-20.

Mordhorst, M. (2016), 'Badwill Branding Denmark', Kommunikationsforum, available at https://www.kommunikationsforum.dk/artikler/En-diskussion-afDanmarks-brand-i-flygtningekrisen [accessed March 9, 2021]

SAS (2020), What Is Truly Scandinavian?, available at https://www.youtube.com/ watch? $\mathrm{v}=$ ShfsBPrNcTI [accessed March 9, 2021]

Stende, T. (2017), 'Is the Nordic Region Best in the World?', Analysis 2017 (76), Nordpub, available at https://www.norden.org/en/publication/nordic-region-bestworld [accessed March 9, 2021]

Strang, J. (ed.) (2016), Nordic Cooperation: A European Region in Transition (London: Routledge).

The Economist (2013), 'The Next Supermodel,' The Economist, February 2.

The White House (2016), 'Remarks by President Obama, President Niinistö of Finland, and Prime Minister Solberg of Norway at the Nordic Leaders' Summit Arrival Ceremony', The White House, available at https://obamawhitehouse. archives.gov/the-press-office/2016/05/13/remarks-president-obama-presidentniinist $\% \mathrm{C} 3 \%$ B6-finland-and-prime-minister [accessed March 9, 2021]

Tømmerbakke, S. G. (2020), 'Danish Historian Welcomes Scotland Back to Scandinavia', High North News, available at https://www.highnorthnews.com/en/danishhistorian-welcomes-scotland-back-scandinavia [accessed March 9, 2021]

World Economic Forum (2011), Shared Norms for the New Reality: The Nordic Way (Davos: World Economic Forum), available at https://www.globalutmaning.se/ wp-content/uploads/sites/8/2011/01/Davos-The-nordic-way-final.pdf [accessed March 9, 2021] 